JOURNAL OF HENAI MATH

p-ISSN: $2615-2185$

e-ISSN: $2615-2193$

\section{JOURNAL OF HONAI MATH}

http://journalfkipunipa.org/index.php/jhm

http://doi.org/10.30862/jhm.v2i2.66

\title{
PEMBELAJARAN KELILING DAN LUAS BANGUN DATAR MENGGUNAKAN METODE MATEMATIKA GASING
}

\author{
Ryky Mandar Sary, Ristiana \\ Universitas PGRI Semarang, Jl. Sidodadi Timur, Semarang 50232, Indonesia \\ Email: Rykymandarsary@gmail.com
}

\begin{abstract}
Abstrak
Pembelajaran matematika adalah suatu proses belajar mengajar yang dibangun oleh guru untuk mengembangkan kreativitas berfikir siswa dalam mengkonstruksi suatu pengetahuan prosedural terhadap materi matematika. Penelitian ini bertujuan untuk mengetahui peningkatan pengetahuan prosedural siswa akibat implementasi metode matematika gasing materi keliling dan luas bangun datar pada siswa kelas IV Sekolah Dasar. Penelitian ini merupakan penelitian kuantitatif. Jenis penelitian ini adalah pre-eksperiment dengan menggunakan desain penelitian one group pretest-posttest. Penelitian mengambil sampel satu kelas yang berjumlah 39 siswa SDN Plamongansari 01 Semarang. Analisis data yang digunakan dalam penelitian ini yaitu menggunakan uji t. Hasil pengujian menunjukkan bahwa Ho ditolak pada taraf kepercayaan 5\%, atau terdapat perbedaan antara nilai siswa pada pretest dan posttest. Hal ini menunjukkan bahwa implementasi metode matematika gasing dapat meningkatkan pengetahuan prosedural siswa Kelas IV Sekolah Dasar pada materi keliling dan luas bangun datar.
\end{abstract}

Kata kunci: Metode Matematika Gasing, Pengetahuan Prosedural, Sekolah Dasar.

\begin{abstract}
Mathematics learning is a teaching and learning process that is built by teachers to develop students's thinking creativity in constructing the procedural knowledge for mathematics. The research aims to determine the increase in students' procedural knowledge of the implementation of Gasing mathematical methods on around and the wide flatness, the subject matter of fourth grade students. This study used quantitative research. The study took a sample of a class of 39 students of SDN Plamongansari 01 Semarang. This type of research uses pre-experiment design with the pretestposttest one group research design. The data obtained were analyzed statistically using the t-test. The test results show that Ho is rejected at the 5\% confidence level, or there is a difference between student scores on pre-test and post-test. It means that the implementation of the mathematical method can improve the procedural knowledge of fourth grade of Elementary School students on the subject matter of circumference and area of planes.
\end{abstract}

Keywords: Math Gasing Method, Procedural Knowledge, Elementary School.

\section{PENDAHULUAN}

Sekolah dasar merupakan jenjang awal dalam sistem pendidikan di Indonesia yang melandasi jenjang pendidikan menengah dan pendidikan tinggi. Undang-Undang Sistem Pendidikan Nasional Nomor 20 Tahun 2003 Pasal 37 menjelaskan bahwa pembelajaran di 
sekolah dasar mencakup berbagai muatan mata pelajaran, salah satu muatan yang penting untuk dipelajari pada jenjang ini adalah matematika. Disisi lain, perlu bagi semua orang untuk mengenal matematika, memahami peran dan manfaat matematika ke depan (Hamzah dan Muhlisrarini, 2014). Sehingga, materi matematika menjadi salah satu materi yang harus dikuasai oleh siswa sekolah dasar.

Hasil wawancara bersama guru di kelas IV salah satu SD Negeri di Kota Semarang diketahui bahwa permasalahan di kelas pada saat proses belajar mengajar matematika bahwa "proses belajar matematika berjalan dengan lancar dan sebagian siswa mengikuti pelajaran dengan aktif. Namun disini timbul permasalahan, masih ada siswa yang belum bisa menyelesaikan soal matematika dengan langkah-langkah yang benar". Selain itu keaktifan siswa saat pembelajaran dikelas yaitu "masih banyak siswa yang tidak aktif bahkan cenderung bosan atau malas”. Kendala yang dihadapi guru di kelas IV salah satu SD Negeri di Kota Semarang adalah " masih ada siswa yang belum menguasai rumus dan belum hafal tentang perkalian dan pembagian". Kendala tersebut dapat mempengaruhi hasil belajar siswa bahwa " hasil belajar siswa pada mata pelajaran matematika dengan materi keliling dan luas bangun datar lebih dari 50\% jumlah siswa yang belum mencapai KKM yang ditentukan, yaitu 65".

Permasalahan yang dihadapi siswa Kelas IV SD Negeri di Kota Semarang tergolong permasalahan tingkat dasar dalam pembelajaran Matematika. Salah satu cara yang dapat dilakukan untuk mengatasi permasalahan ini adalah penerapan metode pembelajaran yang tepat. Metode Matematika Gasing adalah salah satu yang dapat diimplementasikan dalam pembelajaran matematika.

Metode Gasing adalah cara belajar matematika secara Gampang, ASylk, dan MenyenaNGkan (Surya, 2018; Armianti, dkk. 2016). Shanty dan Wijaya (2012) mendeskripsikan Matematika GASING sebagai proses pembelajaran yang membuat siswa belajar secara easy, fun, and enjoyable. Melalui Metode Gasing, siswa tidak hanya menghafal rumus yang diberikan guru, tetapi dapat mempelajari bagaimana menemukan rumus tersebut (Prahmana \& Suwasti, 2014). Sehingga, metode Gasing dapat dijadikan salah satu solusi untuk menyelesaikan problematika pembelajaran matematika siswa, salah satunya pembelajaran keliling dan luas bangun datar.

Implementasi metode gasing dalam pembelajaran keliling dan luas bangun datar pada mata pelajaran matematika diharapkan dapat menambah variasi metode 
pembelajaran di kelas. Syarif (2015) dan Prahmana (2017) menjelaskan bahwa Metode matematika Gasing adalah suatu metode pembelajaran matematika dengan menggunakan cara yang lebih sederhana serta pembelajarannya dapat dipadukan dengan pendekatan logika dan meminimalisir penggunaan rumus serta menekankan kepada suatu pembelajaran yang berupa kegiatan eksplorasi nyata (konkret) dari materi-materi yang disesuaikan dengan kurikulum sekolah.

Berdasarkan latar belakang masalah tersebut, dapat diidentifikasi bahwa proses belajar masih terpaku pada buku, guru sudah mengadakan variasi media, namun masih kurang optimal mengadakan variasi model dan metode pembelajaran. Hal ini berakibat kepada siswa yang menjadi kurang begitu memperhatikan saat pelajaran berlangsung (Mumu \& Tanujaya, 2018; Mahmud, dkk. 2019; Jemudin, Makur, \& Ali, 2019; Astutik \& Aniningsih, 2019; Aini \& Sumargiyani, 2018). Disisi lain, hasil beberapa penelitian menunjukkan bahwa metode matematika Gasing dapat memperbaiki proses pembelajaran dan meningkatkan hasil belajar matematika (Syarif, 2015; Prahmana, 2017; Prahmana \& Suwasti, 2014; Armianti, dkk. 2016; Shanty \& Wijaya, 2012; Nuari, dkk. 2019). Sehingga, penelitian ini bertujuan untuk mengidentifikasi ada tidaknya peningkatan pengetahuan prosedural siswa kelas IV Sekolah Dasar melalui implementasi metode matematika gasing pada materi pelajaran keliling dan luas bangun datar.

\section{METODE PENELITIAN}

Penelitian ini adalah pre-eksperimental dengan menggunakan desain penelitian One-Group Pretest-Postest, dengan mengimplementasikan metode Matematika Gasing pada materi pembelajaran keliling dan luas bangun datar. Adapun pengetahuan prosedural merupakan hasil yang ingin dilihat setelah proses pembelajaran.

Penelitian ini dilakukan di SD Negeri Plamongansari 01, Kecamatan Pedurungan, Kota Semarang. Subyek yang digunakan dalam penelitian ini adalah siswa kelas IV SD Negeri Plamongansari 01 Semarang yang berjumlah 39 siswa. Pengumpulan data menggunakan instrument tes. Instrumen tes dalam bentuk tes tertulis dilaksanakan sebelum proses pembelajaran (pre-test), dan setelah pembelajaran (post-test). Instrumen tes tersebut masing-masing terdiri dari 6 butir soal dalam bentuk uraian. Sebelum tes diberikan kepada siswa, instrument tes tersebut di validasi secara kualitatif oleh dua dosen dan guru kelas IV SDN Plamongansari 01. 
Pengukuran pengetahuan prosedural siswa sebelum dan sesudah perlakukan dilakukan dengan menggunakan pretest, LKS ke satu, LKS Pertemuan ke dua dan posttest. Pelaksanaan pretest dilaksanakan sebelum mengadakan pembelajaran pada pertemuan pertama. LKS Pertemuan ke satu dilaksanakan pada saat pembelajaran dengan menggunakan metode matematika gasing pada materi luas bangun datar. LKS Pertemuan ke dua dilaksanakan pada saat pembelajaran dengan menggunakan metode matematika gasing pada materi keliling bangun datar. Sedangkan pelaksanaan posttest dilaksanakan setelah pertemuan ke tiga.

Data yang diperoleh dianalisis dengan menggunakan metode statistika, yaitu dengan uji t berpasangan (paired samples t-test). Uji t berpasangan bertujuan untuk membandingkan rataan pengetahuan prosedural sebelum dan sesudah perlakuan sama atau tidak sama (Moore, dkk. 2013). Sehingga, hipotesis yang diuji adalah:

$\mathrm{H}_{0}$ : Tidak terdapat perbedaan nilai rata-rata siswa kelas IV SD, sebelum dan sesudah melaksanakan pembelajaran dengan menggunakan metode Gasing

$\mathrm{H}_{1}$ : Terdapat perbedaan nilai rata-rata siswa kelas IV $\mathrm{SD}$, sebelum dan sesudah melaksanakan pembelajaran dengan menggunakan metode Gasing

Analisis lebih lanjut untuk mengetahui peningkatan pengetahuan prosedural menggunakan uji Normalitas Gain. Uji Normalitas Gain adalah uji yang bertujuan untuk memberikan gambaran tentang peningkatan nilai siswa antara sebelum dan sesudah diterapkan suatu metode pembelajaran (Jumiati, dkk. 2011).

\section{HASIL DAN PEMBAHASAN}

Nilai yang diperoleh siswa, meliputi nilai pada pre-test, LKS pertemuan ke satu, LKS Pertemuan ke dua dan post-test dapat dilihat pada Tabel 1.

Tabel 1. Rekapitulasi Nilai Pre-test, LKS dan Post-test

\begin{tabular}{lcccc}
\hline Nilai & Pre-Test & LKS-1 & LKS-2 & Post Test \\
\hline Jumlah & 1366 & 2799 & 3087 & 2774 \\
Minimum & 15 & 40 & 65 & 35 \\
Maksimum & 86 & 100 & 100 & 100 \\
Rata-rata & 35,026 & 71,769 & 78,923 & 71,128 \\
\hline
\end{tabular}

Tabel 1 menunjukkan bahwa nilai rata-rata siswa pada post-test lebih besar dibandingkan nilai rata-rata siswa yang diperoleh pada pre-test. Peningkatan nilai siswa 
tersebut diduga disebabkan oleh penggunaan metode Gasing. Hal tersebut juga tampak pada nilai yang diperoleh siswa pada dua LKS yang dikerjakan, dengan nilai siswa pada LKS ke dua lebih besar dibandingkan nilai siswa pada LKS pertemuan ke satu. Sehingga dapat dinyatakan bahwa setelah mengerjakan LKS, terdapat peningkatan pengetahuan prosedural siswa pada materi keliling dan luas bangun datar di SDN Plamongansari 01 Semarang.

Meningkatnya nilai siswa setelah mengikuti pelajaran matematika dengan mengimplementasikan metode Gasing juga dilaporkan oleh sejumlah peneliti, antara lain Kolnel, Prahmana, dan Arifin (2015) yang melakukan penelitian di Sekolah Menengah Pertama (SMP), dan Armianti, dkk. (2016) yang melaksanakan penelitian di Sekolah Dasar.

Lebih lanjut dilakukan uji statistika (Uji t) untuk mengetahui apakah terdapat perbedaan nilai yang diperoleh siswa sebelum dan sesudah pembelajaran dengan menggunakan metode Gasing. Hasil analisis statistika dengan menggunakan uji t disajikan pada Tabel 2.

Tabel 2. Hasil analisis uji-t

\begin{tabular}{cccc}
\hline Responden & thitung & tabel & Kesimpulan \\
\hline 39 & 15,146 & 1,991 & $H_{0}$ ditolak \\
\hline
\end{tabular}

Tabel 2 menjelaskan bahwa diperoleh nilai thitung sebesar 15,146 dan nilai tabel sebesar 1,991. Dengan kata lain thitung lebih besar dari tabel, sehingga terdapat cukup bukti untuk menolak H0. Berdasarkan hasil analisis statistika tersebut, maka dapat disimpulkan bahwa pengetahuan prosedural siswa meningkat setelah mengikuti pembelajaran matematika pada materi pelajaran keliling dan luas bangun data, yang mengimplementasikan metode Gasing.

Lebih lanjut untuk mengetahui seberapa besar peningkatan pengetahuan prosedural siswa pada materi keliling dan luas bangun datar, dilakukan dengan menggunakan analisis Uji N-Gain. Hasil uji N- Gain disajikan pada Tabel 3.

Perhitungan uji rata-rata N-gain di atas didapat hasil perhitungan sebesar 0,556, seperti tampak pada Tabel 3. Hasil tersebut menunjukkan bahwa peningkatan pengetahuan procedural siswa dalam dikelompokkan pada kategori sedang. Dengan demikian dapat dinyatakan bahwa terjadi peningkatan pengetahuan prosedural siswa SD 
pada materi keliling dan luas bangun datar, yang cukup baik jika diimpelementasikan metode matematika Gasing.

Tabel 3. Uji N- Gain Nilai Pre-test dan Post-test

\begin{tabular}{ccccc}
\hline \multirow{2}{*}{ Nilai Ideal } & \multicolumn{2}{c}{ Nilai Rata-rata } & \multirow{2}{*}{ Nilai N-Gain } & Kategori \\
\cline { 2 - 3 } & Pre-test & Post-test & & \\
\hline 100 & 35,026 & 71,128 & 0,556 & Sedang \\
\hline
\end{tabular}

Implementasi metode matematika gasing ini mengakibatkan siswa menjadi antusias dalam mengikuti kegiatan pembelajaran. Hasil penelitian ini sesuai dengan teori Piaget dalam Susanto (2013) yang menyatakan bahwa individu pada usia 7 sampai 11 tahun berada pada tahap operasional konkret. Individu pada tahap ini memerlukan aturan dan skenario dalam penggunaan logika untuk menunjang proses belajar.

Keberhasilan metode matematika gasing didukung oleh penelitian terdahulu yang dilakukan oleh Syarif (2015) berpendapat bahwa metode matematika gasing efektif terhadap minat dan hasil belajar siswa materi keliling bangun datar. Hasil penelitian tersebut sesuai dengan hasil penelitian yang dilakukan oleh Kolnel, dkk. (2016). Menurut mereka, terdapat peningkatan pembelajaran metode matematika gasing materi perkalian bilangan dua angka dengan bilangan dua angka dengan rata-rata 0,42 dan kategori sedang. Lebih lanjut, penelitian Langi (2014) yang menyatakan bahwa pembelajaran dengan menggunakan metode matematika gasing dapat meningkatkan hasil belajar siswa. Hasilhasil penelitian tersebut sejalan dengan hasil penelitian Ainurrahmi (2013), yang menyatakan bahwa penerapan metode gasing dapat meningkatkan minat dan kemampuan berhitung mata pelajaran matematika.

\section{SIMPULAN}

Implementasi Metode Matematika Gasing dapat meningkatkan pengetahuan prosedural siswa kelas IV Sekolah Dasar pada materi keliling dan luas bangun datar. Peningkatan pengetahuan proseduran siswa tergolong dalam kelopok sedang.

\section{DAFTAR RUJUKAN}

Aini, N., \& Sumargiyani, S. (2018). Developing mathematics Student Activity Sheel (SAS) in transfornation for seventh grade students of SMP/MTs based curriculum 
2014. Journal of Honai Math, 1(1), 56-66.

Ainurrahmi, N. (2013). Penerapan metode gasing untuk meningkatkan minat belajar dan kemampuan berhitung mapel matematika siswa kelas IV SDN Jepang 1 Kudus Tahun 2012/2013. Skripsi. Surakarta: Universitas Muhammadiyah Surakarta.

Armianti, A., Wildan, D.N., Robiansyah, R., Trissiana, O., \& Prahmana, R.C.I. (2016). Peningkatan kemampuan pemahaman matematis siswa menggunakan pembelajaran Matematika GASING (Gampang, ASyIk, dan menyenaNGkan). Jurnal Elemen, 2(1), 27-38.

Astutik, H. S., \& Aniningsih, P. (2019). Penerapan pembelajaran problem based learning berbantu virtual laboratory ditinjau dari hasil belajar dan kemampuan berpikir logis siswa SMP. Journal of Honai Math, 2(1), 25-36.

Hamzah, A., \& Muhlisrarini. (2014). Perencanaan dan Strategi Pembelajaran Matematika. Jakarta: PT Raja Grafindo Persada.

Jemudin, F. D., Makur, A. P., \& Ali, F. A. (2019). Hubungan sikap belajar dan motivasi belajar terhadap prestasi belajar matematika siswa SMPN 6 Langke Rembong. Journal of Honai Math, 2(1), 1-12.

Jumiati, S.M., \& Akmalia, D. (2011). Peningkatan hasil belajar siswa dengan menggunakan model Numbered Head Together (NHT) pada materi gerak tumbuhan di kelas VII SMP Sei Putih Kampar. Lentera, 2(2), 161-185.

Kolnel, R.P., Prahmana, R.C.I., \& Arifin, S. (2016). Pengaruh pembelajaran matematika gasing pada materi geometri terhadap hasil belajar siswa kelas VII Sekolah Menengah Pertama. Numeracy Journal, 2(1), 62-68.

Langi, E.L. (2014). Metode Gasing: Peningkatan hasil belajar matematika siswa kelas IV SDN 3 kesu' pada materi operasi perkalian dan pembagian melalui implementasi Metode Gasing. Jurnal KIP, 3(2), 589-597.

Mahmud, R. S., Syamsuadi, A., \& Nursakiah, N. (2019). Pembelajaran kooperatif STAD dengan strategi penugasan multi level instruction pada materi matematika. Journal of Honai Math, 2(1), 37-52.

Moore, D.S., Notz, W.I., \& Fligner, N.A. (2013). The Basic Practice of Statistics. New York: W. H. Freeman and Company.

Mumu, J., \& Tanujaya, B. (2018). Desain pembelajaran materi operasi pada himpunan mengunakan permainan "lemon nipis”. Journal of Honai Math, 1(1), 14-23. 
Nuari, L.F., Prahmana, R.C.I., \& Fatmawati, I. (2019). Learning of division operation for mental retardations' student through Math GASING. Journal on Mathematics Education, 10(1), 127-142.

Prahmana, R.C.I. (2017). The hypothetical learning trajectory on addition in Mathematics GASING. Southeast Asian Mathematics Education Journal, 5(1), 49-61.

Prahmana, R.C.I., \& Suwasti, P. (2014). Local instruction theory on division in mathematics GASING. Journal on Mathematics Education, 5(1), 17-26.

Shanty, N.O., \& Wijaya, S. (2012). Rectangular array model supporting students' spatial structuring in learning multiplication. Journal on Mathematics Education, 3(2), 175-186.

Surya, Y. (2018). Matematika Gampang Asyik dan Menyenangkan untuk Siswa SD/MI Kelas IV. Tangerang: PT Kandel.

Susanto, A. (2013). Teori belajar \& Pembelajaran. Jakarta: Prenadamedia Group.

Syarif, H. (2015). Keefektifan Metode Matematika Gasing terhadap minat dan hasil belajar keliling bangun datar siswa kelas III Sekolah Dasar Negeri 1 Kalipancur Kabupaten Pekalongan. Skripsi. Semarang: UNNES 